\title{
Upaya Meningkatkan Keaktifan dan pemahaman Konsep Gaya Magnet Melalui Modul Kartun Berbasis Experiental Learning
}

\author{
Krismayana Megariyani, Elly's Mersina Murs idik, Ivayuni Listiani
}

(C) 2019 JEMS (Jurnal Edukasi Matematika dan Sains)

This is an open access article under the CC-BY-SA license (https://creativecommons.org/licenses/bysa/4.0/) ISSN 2337-9049 (print), ISSN 2502-4671 (online)

\begin{abstract}
Abstrak:
Penelitian ini bertujuan untuk upaya meningkatkan keaktifan dan pemahaman konsep gaya magnet melalui modul kartun berbasis experiential learning pada siswa kelas VI. Penelitian dilakukan pada bulan April 2019 di SDN Gelanglor, Kecamatan Sukorejo, Kabupaten Ponorogo. Jenis penelitian ini adalah penelitian tindakan kelas yang terdiri dari tiga siklus yaitu siklus 1, siklus II dan siklus III. Penelitian ini dilakukan enam kali pertemuan dengan materi gaya magnet.Subjek penelitian adalah peserta didik kelas VI dengan jumlah peserta didik 29 orang. Teknik pengumpulan data dengan cara observasi dan tes. Hasil menujukkan keaktifan dan pemahaman konsep melalui penerapan modul kartun berbasis experiential learning meningkat dengan sangat baik. Prosentase peningkatan keaktifan $100 \%$ dengan nilai rata-rata keaktifan 93,10 dan pemahaman konsep mencapai $100 \%$ dengan nilai rata-rata pemahaman konsep 92,76. Sehingga bisa dilihat kelebihan penerapan modul kartun berbasis experiential learning adalah menjadikan peserta didik lebih aktif, kekurangan dari modul ini adalah membutuhkan waktu yang sangat lama untuk menyiapkan materi pembelajaran yang akan diajarkan.
\end{abstract}

Kata Kunci : Pemahaman konsep; Gaya Magnet; Modul Kartun; Experiental Learning

\begin{abstract}
:
This study aims to improve the activity and understanding of the concept of magnetic force through cartoon modules based on experiential learning in class VI students. The study was conducted in April 2019 at SDN Gelanglor, Sukorejo District, Ponorogo Regency. This type of research is a class action research consisting of three cycles, namely cycle 1 , cycle II and cycle III. This study was conducted six times with magnetic force material. Subjects were class VI students with 29 students. Data collection techniques by observation and tests. The results showed activeness and understanding of the concept through the application of experiential learning-based cartoon modules improved very well. The percentage increase of $100 \%$ activeness with an average value of 93.10 activeness and understanding of the concept reached $100 \%$ with an average value of 92.76 concept understanding. So that it can be seen that the advantages of the application of cartoon modules based on experiential learning is to make students more active, the disadvantage of this module is that it takes a very long time to prepare learning material to be taught.
\end{abstract}

Keywords : Concept Understanding; Magnetic Force; cartoon modules; Experiental Learning

\section{Pendahuluan}

Pendidikan adalah kegiatan mengoptimalkan perkembangan potensi peserta didik dan kecakapan pribadi peserta didik. Kegiatan pendidikan diarahkan kepada pencapaian tujuan yakni tujuan pendidikan nasional Indonesia yang meliputi pengembangan potensi peserta didik 
agar menjadi manusia yang beriman dan bertaqwa kepada Tuhan Yang maha Esa, berakhlak mulia, sehat jasmani dan rohani, mandiri, berilmu, aktif, kreatif, inovatif menjadi warga negara yang bertanggung jawab. Proses belajar mengajar merupakan proses kegiatan pelaksanakan kurikulum dari lembaga pendidikan, agar dapat mempengaruhi peserta didik untuk mencapai tujuan pendidikan.

Guru merupakan penentu atau pemegang peran penting dalam proses belajar peserta didik, melalui pembelajaran yang direncanakan, untuk itu guru harus mampu mengkondisikan agar peserta didik mampu mengikuti proses pembelajaran dengan aktif. Pembelajaran aktif adalah pembelajaran yang memerlukan keterlibatan penuh semua murid dan guru secara fisik, mental, emosional, bahkan spiritual (Kisworo, 2016:). Menurut Kamus Bahasa Indonesia konsep adalah ide atau pengertian yang disarikan dari peristiwa konkret (Agung, 2017). Jadi, pemahaman konsep adalah pemahaman terhadap ide-ide yang diperoleh dari proses belajar dan selanjutnya disimpulkan menjadi pemahaman baru. Pemahaman konsep terhadap materi gaya magnet sangat penting karena materi gaya magnet pada dasarnya pelajaran yang selalu berkembang. Penggunaan modul kartun, alat peraga dan lembar kerja siswa mampu membantu siswa memahami konsep materi gaya magnet. Keaktifan peserta didik dalam proses pembelajaran akan menentukan keberhasilan peserta didik itu sendiri. Pemahaman konsep belajar dibuktikan dengan hasil evaluasi pendalaman materi belajaran dengan perolehan rata-rata diatas KKM.

Suryani (2014) berpendapat bahwa siswa tidak memiliki pengalaman langsung karena objek yang dipelajari tidak nyata, sehingga berdampak pada hasil belajar siswa. Hal tersebut ditunjukkan dengan rata-rata hasil belajar siswa yang masih rendah, yaitu pada tahun pelajaran 2011/2012 adalah 63,85 dengan KKM 65 dan pada tahun pelajaran 2012/2013 adalah 64,82 dengan KKM 70. Rendahnya hasil belajar siswa ini disebabkan karena kurangnya pemahaman konsep dari siswa meskipun guru sudah menerangkan materi pelajaran. Hal ini disebabkan karena guru hanya menggunakan satu macam metode belajar yaitu ceramah, sehingga perkembangan kognitif anak hanya akan mengarah kepada verbalisme dan menjadi kurang bermakna (Munif, 2009).

Sejalan dengan pendapat di atas hasil observasi yang dilakukan peneliti telah ditemukan keaktifan dan pemahaman konsep rendah terbukti karena pada saat proses kegiatan belajar mengajar di SDN 1 Gelanglor Desa Gelanglor, Kecamatan Sukorejo kurang adanya variasi. Penerapan model pembelajaran tidak menarik, tidak memanfaatkan media yang ada dan media yang ada kurang menarik menyebabkan peserta didik tidak semangat untuk mengikuti kegiatan belajar mengajar, pada saat proses pembelajaran berlangsung terdapat siswa keluar masuk kelas, ramai sendiri atau tidak memperhatikan penjelasan guru, bermain dengan temannya, belum ada dorongan untuk belajar di kelas hingga menyebabkan suasana kelas tidak kondusif dan keaktifan peserta didik tidak tampak dan berkembang. Adanya modul kartun berbasis experiential learning, dapat meningkatkan keaktifan sehingga pemahaman konsep terhadap materi yang dipelajari dapat meningkat.

Proses pembelajaran agar dapat berlangsung secara optimal, perlu digunakannya modul pembelajaran yang menarik. Modul tersebut adalah modul kartun berbasis experiential learning. Modul kartun berbasis experiential learning adalah perangkat pembelajaran berupa buku dengan gambar-gambar yang bervariasi dan menarik untuk menyampaikan pembelajaran dengan berbagai eksperimen. Modul kartun berbasis experiential learning menjadikan peserta 
didik dapat belajar melalui pengalaman atau peristiwa yang dialaminya sendiri dengan melalui simulasi maupun melalui pengalaman langsung.

Pemilihan modul kartun dapat meningkatkan keaktifan belajar siswa karena karakteristik anak SD yang masih menyukai hal-hal yang konkrit sehingga modul kartun juga dapat meningkatakan pemahaman terhadap materi pelajaran yang disampaikan karena dilengkapi dengan gambar-gambar yang mereka sukai dan dapat mendorong siswa lebih aktif, kreatif dan inovatif terhadap materi pembelajaran yang selaras dengan kehidupan sehari-hari di lingkungannya. Modul pembelajaran seperti yang disampaikan diatas sangat dibutuhkan dalam penyampaian materi gaya magnet, khususnya bagi peserta didik sekolah dasar. Untuk meningkatkan keaktifan belajar melalui modul kartun berbasis experiential learning pada siswa Sekolah Dasar.

\section{Metode}

Penelitian tindakan bertujuan untuk mengembangkan keaktifan dan pemahaman konsep baru atau cara pendekatan baru untuk memecahkan masalah dengan penerapan langsung pada kehidupan sehari-hari. Metode penelitian yang digunakan untuk memecahkan masalah di atas adalah Penelitian Tindakan Kelas (PTK).Ada empat tahap yang harus dilaksanakan yakni perencanaan, pelaksanaan, pengamatan, dan refleksi (Arikunto, 2010). Teknik pengumpulan data adalah sebagian informasi yang diterimanya tentang suatu kenyataan atau fenomena empiris, wujudnya dapat berupa seperangkat ukuran (kuantitatif, berupa angka-angka) atau berupa ungkapan kata-kata (verbalize) atau kualitatif (Noor, 2011). Teknik pengumpulan data adalah kegiatan untuk memperoleh data, dalam penelitian ini peneliti tidak hanya mengajar saja melainkan harus meneliti dari semua proses kegiatan dalam pembelajaran. Sedangkan pengumpulan data, peneliti menggunakan beberapa teknik yang sesuai dengan penelitian ini. Penelitian ini menggunakan teknik test dan teknik non-test. Teknik non-test pengumpulan data tentang keaktifan dapat dilakukan dengan observasi, dan dokumentasi. Selanjutnya teknik test dilakukan dengan memberikan pre-test dan post-test/evaluasi untuk memperoleh data tentang pemahaman konsep materi gaya magnet peserta didik di SDN 1 Gelanglor. Analisis data adalah suatu proses mencari dan mengatur hasil observasi/pengamatan, tes dan dokumentasi secara berurutan yang berupa catatan lapangan dan bahan-bahan lain yang telah dikumpulkan oleh peneliti, untuk menambah pemahaman peneliti sendiri mengenai bahan-bahan itu semua dan untuk memungkinkan peneliti melaporkan apa yang ditemukan kepada pihak- pihak lain. Analisi data adalah sebagai berikut: 1) Analisis data peningkatan keaktifan peserta didik dikatakan meningkat apabila indikator keaktifan mencapai skor $\geq 75$; 2) Analisis data peningkatan pemahaman konsep peserta didik dikatakan meningkat apabila indikator pemahaman konsep mencapai $80 \%$ peserta didik memperoleh nilai $\geq 75$ atau diatas KKM.

\section{Hasil dan Pembahasan}

Hasil penelitian pada siklus I, siklus II, dan siklus III tentang kekatifan dan pemahaman konsep peserta didik dapat diketahui bahwa terjadi peningkatan. Peningkatan keaktifan dan 
pemahaman konsep peserta didik dapat diuraikan sebagai berikut: Data peningkatan kekatifan belajar peserta didik pada siklus I, II dan III dapat disajikan pada tabel 2 di bawah ini:

Tabel 1. Peningkatan Keaktifan Belajar Peserta Didik.

\begin{tabular}{ccccccc}
\hline Data yang diperoleh & \multicolumn{6}{c}{ Hasil } \\
\cline { 2 - 7 } & \multicolumn{2}{c}{ Siklus I } & \multicolumn{2}{c}{ Siklus II } & \multicolumn{2}{c}{ Siklus III } \\
\cline { 2 - 7 } & $\mathrm{F}$ & $\%$ & $\mathrm{~F}$ & $\%$ & $\mathrm{~F}$ & $\%$ \\
\hline $\begin{array}{c}\text { Peserta didik yang } \\
\text { memiliki keaktifan aktif } \\
\text { dan sangat aktif. }\end{array}$ & 2 & $7 \%$ & 15 & $52 \%$ & 29 & $100 \%$ \\
\hline
\end{tabular}

Berdasarkan tabel 1 menunjukkan bahwa keaktifan belajar peserta didik pada siklus I keaktifan sebesar 7\%, pada siklus II keaktifan sebesar 52\% kemudian pada siklus III yang aktif dan sangat aktif meningkat mencapai $100 \%$ dan mencapai indikator keaktifan belajar peserta didik secara klasikal, sehingga tidak perlu dilakukan pebaikan pada siklus berikutnya. Berdasarkan hasil yang disajikan dalam tabel dapat disimpulkan bahwa upaya meningkatkan keaktifan dan pemahaman konsep gaya magnet melalui modul kartun berbasis experiential learning pada siswa kelas VI SDN Gelanglor Kecamatan Sukorejo Ponorogo tahun pelajaran 2018/2019 mampu meningkatkan keaktifan peserta didik. Keaktifan belajar peserta didik meningkat setelah diterapkanya modul kartun berbasis experiential learning.

Peningkatan pemahaman konsep belajar peserta didik pada siklus I, II, dan III dapat disajika melalui tabel 2 di bawah ini:

Tabel 2. Peningkatan Keaktifan Belajar Peserta Didik.

\begin{tabular}{|c|c|c|c|c|c|c|c|}
\hline \multirow{3}{*}{$\begin{array}{l}\text { Data yang } \\
\text { diperoleh }\end{array}$} & \multirow[t]{3}{*}{ Kriteria } & \multicolumn{6}{|c|}{ Hasil } \\
\hline & & \multicolumn{2}{|c|}{ Siklus I } & \multicolumn{2}{|c|}{ Siklus II } & \multicolumn{2}{|c|}{ Siklus III } \\
\hline & & $\mathrm{F}$ & $\%$ & $\mathrm{~F}$ & $\%$ & $\mathrm{~F}$ & $\%$ \\
\hline Nilai $\geq 75$ & Tuntas & 10 & $34 \%$ & 16 & $55 \%$ & 29 & $100 \%$ \\
\hline Nilai $<75$ & Tidak Tuntas & 19 & $66 \%$ & 13 & $45 \%$ & 0 & $0 \%$ \\
\hline \multicolumn{2}{|c|}{ Total } & 29 & $100 \%$ & 29 & $100 \%$ & 29 & $100 \%$ \\
\hline
\end{tabular}

Tabel 2 menunjukkan bahwa pemahaman konsep belajar peserta didik dari siklus I ke siklus II kemudian siklus III mengalami peningkatan pada pembelajaran materi gaya magnet. Berdasarkan tabel di atas perbandingan peserta didik tuntas dan tidak tuntas berbanding terbalik antara pembelajaran siklus I, siklus, II dan siklus III. Ketuntasan pemahaman konsep secara klasikal pada siklus I yang semula sebesar $34 \%$ menjadi $55 \%$ pada siklus II dan mengalami peningkatan pada siklus III mencapai $100 \%$. Peserta didik yang belum tuntas dalam pemahaman konsep secara klasikal yaitu 66\% pada siklus I, 45\% pada siklus II, dan $0 \%$ pada siklus III.

Berdasarkan tabel di atas dapat disimpulkan bahwa upaya meningkatkan keaktifan dan pemahaman konsep gaya magnet melalui modul kartun berbasis experiential learning pada siswa kelas VI SDN Gelanglor Kecamatan Sukorejo Ponorogo tahun pelajaran 2018/2019 mampu meningkatkan pemahaman konsep peserta didik.

Penerapan modul kartun berbasis experiential learning dapat meningkatkan keaktifan dan pemahaman konsep peserta didik, sehingga secara tidak langsung keaktifan peserta didik akan berpengaruh pula pada peningkatan pemahaman konsep peserta didik. Demikian dapat ditarik 
kesimpulan bahwa penerapan modul kartun berbasis experiential learning cocok digunakan bagi yang ingin meningkatkan kekatifan dan pemahaman konsep pada peserta didik.

Kelebihan dari modul kartun berbasis experiential learning adalah sebagai berikut: peserta didik lebih tertarik dalam mengikuti pembelajaran, peserta didik lebih mudah memahami pelajaran, peserta didik dapat memahami petunjuk untuk melakukan kegiatan belajar yang disampaikan oleh guru, peserta didik lebih senang melakukan kegiatan belajar terutama melakukan eksperimen, sehingga peserta didik terpacu untuk berinovasi, membuat peserta didik lebih aktif ,kreatif dan mndiri. Kekurangan dari modul kartun berbasis experiential learning adalah sebagai berikut: pembelajarn membutuhkan waktu yang lama terutama menyiapkan modul kartun berbasis experiential learning, peserta didik hanya mau belajar jika ada media yang menarik saja. terkadang sebagian peserta didik sulit untuk diminta melakukan percobaan.

Ada peningkatan keaktifan dan pemahaman konsep dengan modul kartun berbasis experiential learning. Modul kartun ini menggunakan model experiential learning menggunakan langkah-langkah antara lain, menampilkan ilustrasi, petunjuk melakukan percobaan, ada pembahasan materi, ada permainan yang dapat menarik peserta didik untuk aktif belajar. Kelebihan modul ini juga memuat berbagai percobaan-percobaan yang sangat menarik, karena desain gambar kartun yang lucu dan penuh dengan warna. Modul kartun ini dapat meningkatkan keaktifan siswa untuk melakukan percobaan-percobaan dengan bimbingan guru maupun secara mandiri, melalui percobaan yang dilakukan peserta didik mendapatkan pengalaman yang nyata sehingga dapat diterapkan pada kehidupan sehari-hari dan mampu memecahkan masalah yang ada disekitarnya.

Penggunaan modul kartun berbasis experiential learning ini peserta didik menjadi aktif dalam mendengarkan penjelasan guru, aktif berkerjasama, aktif bereksperimen dan aktif berpendapat. Pembelajaran menggunakan modul kartun berbasis experiential learning di SDN 1 Gelang lor kelas VI sudah berjalan dengan baik. Guru peneliti, dan peserta didik sudah terjalin interaksi dengan baik. Selanjutnya, melalui modul kartun berbasis experiential learning dan melakukan percoban-percobaan dapat juga meningkatkan pengetahuan, pemahaman konsep dan peserta didik mudah ingat pada materi yang diajarkan. Peningkatan pemahaman konsep terbukti dengan adanya peningkatan hasil evaluasi belajar.

Penelitian ini didukung oleh penelitian yang relevan dengan judul "Penerapan metode experiential learning pada pembelajaran IPA untuk meningkatkan hasil belajar siswa sekolah dasar" yang dilaksanakan oleh Munif (2009). Hasil penelitian tersebut menunjukkan bahwa penerapan metode experiential learning pada pembelajaran sains IPA mampu meningkatkan hasil belajar peserta didik kelas lima SD Hal ini ditunjukkan dengan peningkatan nilai rata-rata dan ketuntasan belajar peserta didik.

\section{Simpulan}

Kesimpulan pada penelitian ini adalah sebagai berikut: upaya meningkatkan keaktifan peserta didik dengan menggunakan modul kartun berbasis experiential learning melalui kegiatan inti sebagai berikut: siswa secara berkelompok mengamati modul kartun berbasis experiential learning materi gaya magnet. Setelah mengamati modul, siswa melakukan eksperimen materi gaya magnet tentang pengertian magnet, sifat- sifat magnet, magnet alam, magnet buatan dan kegunaan magnet pada kehidupan sehari-hari yang ada dalam modul. Selanjutnya setiap kelompok secara bergantian mempresentasikan hasil setiap kegiatan 
eksperimen yang telah dilakukan. Langkah-langkah pada modul kartun berbasis experiential learning diatas terbukti dapat meningkatkan keaktifan peserta didik, u paya meningkatkan pemahaman konsep peserta didik menggunakan modul kartun berbasis experiential learning dengan tampilan modul penuh dengan gambar kartun yang menarik dan bervariasi, penuh warna, disertai petunjuk melakukan percobaan yang dapat dilakukan oleh peserta didik dengan bimbingan peneliti maupun secara mandiri, serta pembahasan materi yang jelas dan mengasyikan. Kegiatan modul tersebut ditekankan pada kegiatan- kegiatan nyata sehingga peserta didik mudah memahami dan mengingat materi yang dipelajari. Jadi, modul kartun berbasis experiential learning diatas terbukti dapat meningkatkan pemqahaman peserta didik. Sehingga dapat disimpulkan bahwa penerapan modul kartun berbasis experiential learning dapat meningkatkan keaktifan dan pemahaman konsep belajar peserta didik kelas VI SDN 1 Gelanglor, Kecamatan Sukorejo, Kabupaten Ponorogo

Saran untuk penelitin lanjut, peneliti dalam pembelajaran materi gaya magnet dan menerapkan modul kartun berbasis experiential learning, peneliti selanjutnya diharapkan mampu mengembangkan kreatifitas dan inovasi dengan menggunakan modul kartun berbasis experiential learningyang lebih menarik dan bervariasi, agar peserta didik sepenuhnya dapat terlibat langsung dalam proses belajar mengajardan selanjutnya dapat meningkatkan keaktifan dan pemahaman konsep peserta didik yang lebih baik, serta mampu menerapkan materi tersebut dalam kehidupan sehari-hari. Untuk penerpan hasil penelitian guru diharapkan dapat menerapkan penggunaan modul kartun berbasis experiential learning dengan tepat sesuai situasi dan kondisi kelas dan diharapkan guru mampu lebih kreatif dan inovatif dalam penggunaan modul kartunberbasis experiential learninguntuk menarik peserta didik hingga mampu meningkatkan keaktifan dan pemahaman konsep. Selanjutnya kepala sekolah dan pihak sekolah diharapkan berkerjasama demi kelancaran pengadaan dan penggunaan modul kartunberbasis experiential learning. Bagi peserta didik penggunaan modul kartun berbasis experiential learning dapat mendorong peserta didik untuk mau dan mampu secara mandiri untuk meningkatka keaktifan dan pemahaman konsep belajar. jSelanjutnya pesera didik dapat menerapkan konsep belaja rtersebut dalam kehidupan sehari-hari.

\section{Daftar Rujukan}

Agung, E. (2017). Kamus Bahasa Indonesia. Jakarta: Gramedia Widia Sarana Indonesia.

Arikunto, S. (2010). Penelitian Tindakan. Yogyakarta: Aditya Media.

Munif, I. R. S. (2009). Penerapan Metode Experiential Learning Pada Pembelajaran IPA Untuk Meningkatkan Hasil Belajar Siswa Sekolah Dasar. Jurnal Pendidikan Fisika Indonesia, 5(2).

Noor, J. (2011). Metode Penelitian Skripsi, Tesis, Disertasi dan Kaya Ilmiah. Jakarta: Kencana Prenada Media Grup.

Silberman, M. (2014). Handbook Of Experiential Learning Strategi Pembelajaran Dunia Nyata. Bandung: Penerbit Nusa Media.

Silberman, M. L. (2006). Active Learning; 101 Cara Belajar Siswa Aktif. Bandung: Penerbit Nuansa.

Suryani, S., Rudyatmi, E., \& Pribadi, T. A. (2014). Pengaruh Experiential Learning Kolb melalui Kegiatan Praktikum Terhadap Hasil Belajar Biologi Siswa. Journal of Biology Education, 3(2).

Susilana, R. \& Riana, C. (2019). Media Pembelajaran. Bandung: Wacana Prima. 
Wibowo, N. (2016). Upaya Peningkatan Keaktifan Siswa Melalui Pembelajaran Berdasarkan Gaya Belajar di SMK Negeri 1 Saptosari. Elinvo (Electronics, Informatics, and Vocational Education), 1(2), 128-139. 